\title{
Innovative methods of monitoring for deformations of man-made loaded areas
}

\author{
Svetlana Sheina ${ }^{1, *}$, and Lidia Girya ${ }^{1}$ \\ ${ }^{1}$ Don State Technical University, Gagarin square 1, Rostov-on-Don, 344000, Russia
}

\begin{abstract}
This article presents the technique of RS data use for monitoring of man-made loaded environment deformations in municipalities, explores the methods of geological hazards forecasting. Based on the results of the research conducted in the territory of Rostov-on-Don, areas of geological hazards expressed by ground surface subsidence have been detected.
\end{abstract}

\section{Relevance}

At the present time there are explicit hazardous manmade processes in big cities, such as subsiding deformations of loess soil, ground surface subsidence, ground water rise, soil slips, karst processes and others. With the development of existing and new territories the current monitoring of hazardous processes should be improved for their sustainability. [1-5]

The main issue in information gathering on the parameters of such processes is that they are unevenly distributed geographically and over time. The lack of data is a result of high economic, labour costs and technical difficulties of their obtaining. That makes it difficult to forecast the hazardous geological processes and phenomena, which impedes making efficient decisions on ground protection. Modern innovative technologiesof Earth remote sensing (ERS) could help in the matter. They enable non-contacting studying of immense territories to a high precision,assessing of process dynamics for an extended period of time, detecting of zones of uneven ground subsidence that can arise from existence of hazardous geological processes and phenomena.

\section{State of knowledge of the matter and research task Interferometric survey}

Using the method of phase shift in reflection response for remote radar sensing was first suggested by D. Richman in 1972. [2] But its practical use was hindered by inadequate technical capabilities. The first survey results under the proposed methodology were obtained only in 1986-1989 by R. M. Goldstein and H. A. Zebker [3], following which specified demands on accuracy of space vehicle equipment were formulated.

Persistent Scatterer Interferometry was developed in 1999 in Milan Polytechnic University. The analysis of multipass chains of interferometric radar surveys (30 and more surveys provide the maximum accuracy of estimation of vertical surface deformations (2-4 mm). It is implemented in consistent execution of several stages [3].

At the first stage, radar scan of surface is carried out by two radars simultaneously, and interferometric chain of radar images is obtained. At the second stage, the images are processed. The entire algorithm of interferometric processing is implemented in the software system SARscape (the developer is SARMAP, Switzerland), incorporated in the programme ENVI (Exelis VIS, USA) [7].

As a result of calculations, average annual shift velocity, graph of vertical shifts for the period of 30 surveys for any fixed point can be determined. The data obtained are used for mapping of ground surface shifts, high-precision measurements of building deformations.

At the present time the application of such methods is growing rapidly, and their opportunities are steadily increasing.

Today there are series of consecutive images for the territory of Russia, radar images which can be processed by interferometric techniques with obtaining maps of shifts and deformations of buildings and ground surface for the period of 20 years and more. Since 2002 the satellite ENVISAT with onboard radar ASAR was launched. Its surveys are performed using the regime that allows to combine the results with the products from satellites ERS-1 и 2, which provides the creation of digital elevation models with 20-metre spatial resolution. In 1995 Canada launched the satellite Radarsat-1, able to conduct shooting with spatial resolution from 100 to 7 $\mathrm{m}$, and broad angle and frame area variation. Next satellite Ralarsat-2 (2007) had 1-100-metre spatial resolution and better aspect ratio. With 1-metre resolution the image area is $18 \times 8 \mathrm{~km}$, and with $7 \mathrm{~m} \mathrm{-}$ 150x170 km, $3 \mathrm{~m}-50 \times 50 \mathrm{~km}$.

Authors' suggested approach to the monitoring of deformations of industrial and civil constructions is based on the application of results on ground surface remote sensing, carried out with multipass radar

*Corresponding author: rgsu-gsh@mail.ru 
interferometric survey technique [3]. It consists in recording of radar signal reflected from the ground surface at very short wavelengths by space vehicles. Measurement results processing on several dozens of images allows to determine the position of satellite in space with high precision, to measure the distance to reflective surfaces, and to control the shifts of monitored objects in millimetric range. Multiple surveys of one and the same area from recurrent satellite orbits allow to record the shifts over the years.

\section{The using of monitoring system for the deformations of man-made loaded territories}

Since 2003 the scientists of RSSU at the Department of Urban building and economy were studying the monitoring system of geotechnical conditions. As source material the maps of K. A. Merkulova, the leading expert of «RostovDonTisiz» (on geotechnical conditions, ground water level, rate of ground water level rise), were taken and digitized in ArcGIS. Software product for the analysis of geotechnical surveys results was developed [2].

Classification of geological risk by rate of ground water level rise based on the analysis of hazardous geotechnical processes was developed, presented in Table 1. The map of geological risk, based on it, was charted in Rostov-on-Don using the software package ArcView, presented in Figure 1.

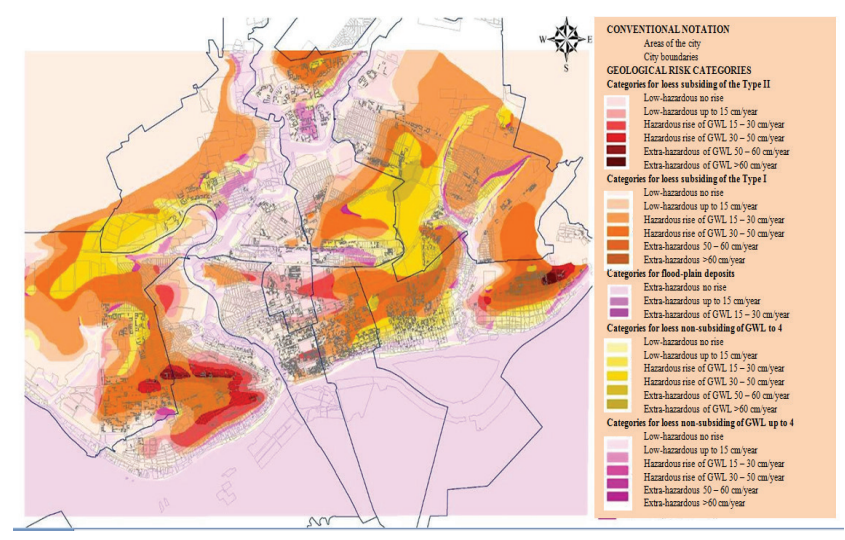

Fig. 1. Electronic map of Rostov-on-Don with geological risk zones.

In order to enhance the monitoring system the remotely sensed data from radar satellites COSMOSkyMed-1-4 (e-GEOS, Italy) for the period of May 2011 to November 2013(40 images) (Figure 2) was procured by the scientists at the Department of Urban building and economy of DSTU. Spatial resolution $-3 \mathrm{~m}$, image area $-40 \times 40 \mathrm{~km}$, length of wave $-3.1 \mathrm{~cm}$. Image processing is performed with EXELIS VIS:ENVI и SARscape Interferometric Stacking software products. Figure 3 shows the data of interferometric survey, presented in the form of point objects, holding information about vertical shifts of ground surface.

As a result of ERS data analysis conducted in Rostov-on-Don, Figure 3 shows the areas with hazardous shifts of ground surface, which in their turn, cause the deformation of buildings and constructions, bridges, roadbed, railway lines and others.

Table 1. Classification of geological risk by rate of ground water level rise.

\begin{tabular}{|c|c|c|c|c|}
\hline $\begin{array}{l}\text { Group of } \\
\text { geological } \\
\text { engineering } \\
\text { conditions }\end{array}$ & $\begin{array}{c}\text { Geological } \\
\text { engineering } \\
\text { conditions }\end{array}$ & $\begin{array}{c}\text { Ground } \\
\text { water } \\
\text { depth } \\
\text { level }\end{array}$ & $\begin{array}{l}\text { Rate of } \\
\text { GWL } \\
\text { rise, } \\
\text { cm/year }\end{array}$ & $\begin{array}{c}\text { Risk } \\
\text { categories }\end{array}$ \\
\hline \multirow{6}{*}{1} & \multirow{6}{*}{$\begin{array}{l}\text { Loess } \\
\text { subsiding of } \\
\text { the Type II }\end{array}$} & \multirow{6}{*}{$>8(10)$} & No rise & \multirow{2}{*}{$\begin{array}{c}\text { Low- } \\
\text { hazardous }\end{array}$} \\
\hline & & & up to 15 & \\
\hline & & & $15-30$ & \multirow{2}{*}{ Hazardous } \\
\hline & & & $30-50$ & \\
\hline & & & $50-60$ & \multirow{2}{*}{$\begin{array}{c}\text { Extra- } \\
\text { hazardous }\end{array}$} \\
\hline & & & $>60$ & \\
\hline \multirow{6}{*}{2} & \multirow{6}{*}{$\begin{array}{c}\text { Loess } \\
\text { subsiding of } \\
\text { the Type I }\end{array}$} & \multirow{6}{*}{$3-8 \mathrm{~m}$} & No rise & \multirow{2}{*}{$\begin{array}{c}\text { Low- } \\
\text { hazardous }\end{array}$} \\
\hline & & & up to 15 & \\
\hline & & & $15-30$ & \multirow{2}{*}{ Hazardous } \\
\hline & & & $30-50$ & \\
\hline & & & $50-60$ & \multirow{2}{*}{$\begin{array}{c}\text { Extra- } \\
\text { hazardous }\end{array}$} \\
\hline & & & $>60$ & \\
\hline \multirow{3}{*}{3} & \multirow{3}{*}{$\begin{array}{c}\text { Flood-plain } \\
\text { deposits }\end{array}$} & \multirow{3}{*}{$0.5-3 \mathrm{~m}$} & No rise & \multirow{3}{*}{$\begin{array}{c}\text { Extra- } \\
\text { hazardous }\end{array}$} \\
\hline & & & up to 15 & \\
\hline & & & $15-30$ & \\
\hline \multirow{6}{*}{4} & \multirow{6}{*}{$\begin{array}{l}\text { Loess non- } \\
\text { subsiding }\end{array}$} & \multirow{6}{*}{$2.5-4 \mathrm{~m}$} & No rise & \multirow{2}{*}{$\begin{array}{c}\text { Low- } \\
\text { hazardous }\end{array}$} \\
\hline & & & up to 15 & \\
\hline & & & $15-30$ & \multirow{2}{*}{ Hazardous } \\
\hline & & & $30-50$ & \\
\hline & & & $50-60$ & \multirow{2}{*}{$\begin{array}{c}\text { Extra- } \\
\text { hazardous }\end{array}$} \\
\hline & & & $>60$ & \\
\hline 5 & $\begin{array}{l}\text { Loess non- } \\
\text { subsiding }\end{array}$ & $\begin{array}{c}4.1-10 \\
\mathrm{~m}\end{array}$ & No rise & $\begin{array}{c}\text { Low- } \\
\text { hazardous }\end{array}$ \\
\hline
\end{tabular}

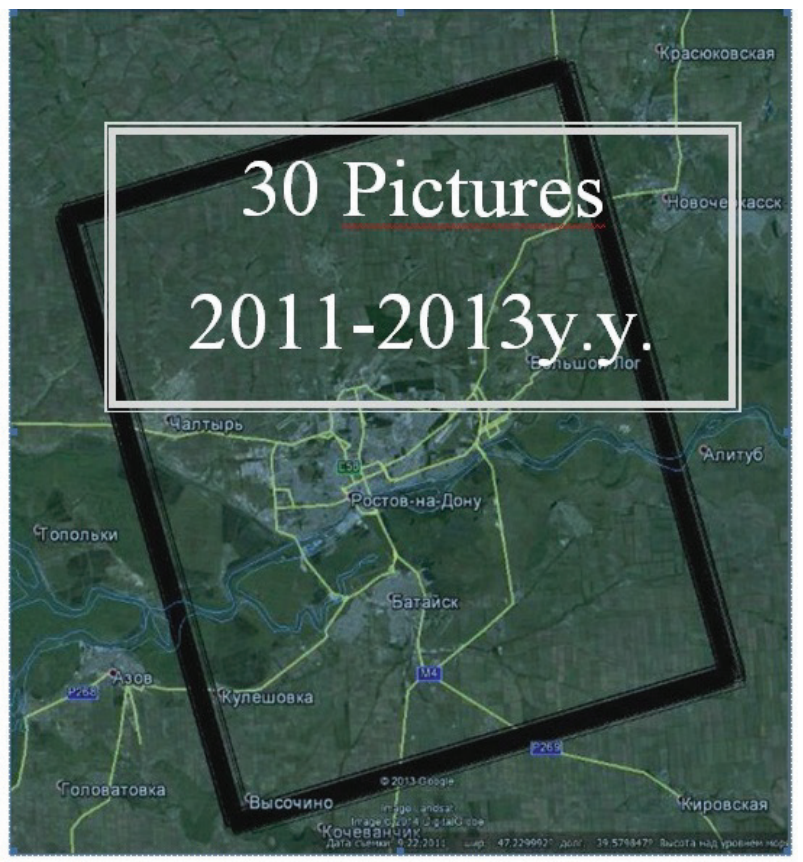

Fig. 2. Plot coverage Rostov-on-Don with satellite data COSMO-SkyMed-1-4 (e-Geos. Italy) for the period of May 2011 to November 2013. 


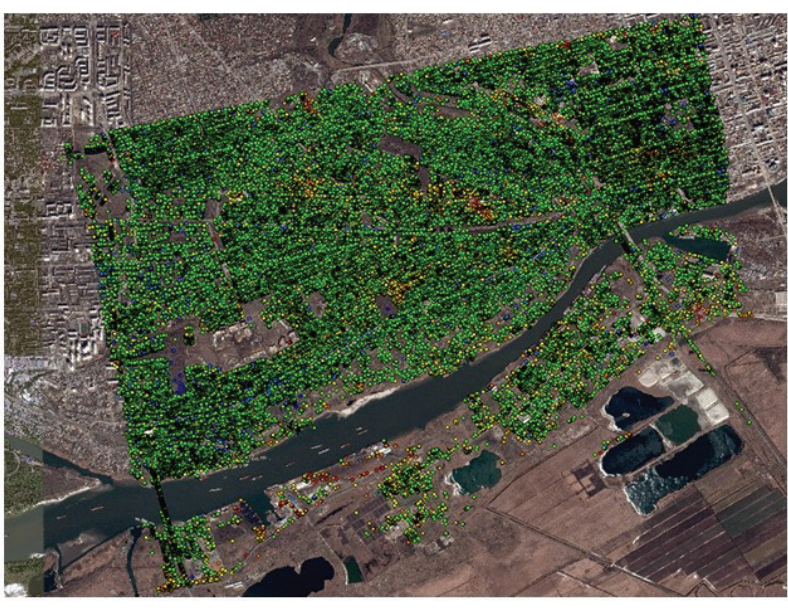

Fig. 3. Focuses of vertical shifts, Rostov-on-Don.

The comparison of electronic maps with the focuses of vertical shifts based on ERS data, and electronic map of Rostov-on-Don with geological risk data allowed to define the most hazardous zones of ground surface subsiding in the areas of hazardous geological processes (Figure 4).

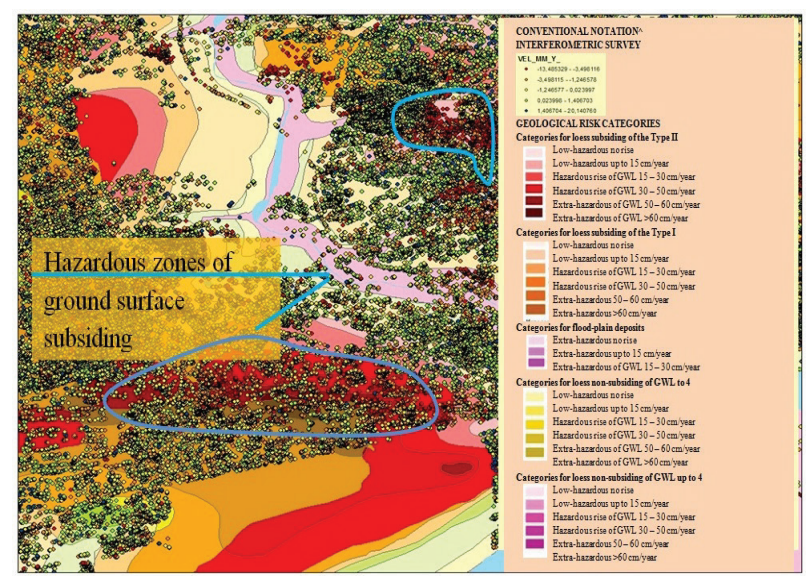

Fig. 4. Plot coverage Rostov-on-Don with satellite data COSMO-SkyMed-1-4 (e-Geos. Italy) for the period of May 2011 to November 2013.

In particular, the electronic map with zones of geological risk indicates the possibility of hazardous geological processes of the second group on subsiding of the second type, as can be seen from remotely sensed data.

\section{Abstracts}

An advantage of using the interferometric survey over the geodetic observations is that the large area rather than single object is covered, and the acquisition of data on vertical deformations of surface is less labourintensive.

Comparison of remotely sensed data with data from monitoring of hazardous geological processes using geotechnical results gives a complete and reliable picture on technological hazards that allows, in its turn, to make adequate managerial decisions aimed at reduction of natural or man-made hazards in the development of built-up areas.

\section{References}

1. A.V. Gridnevskiy, Inzhenernyy Vestnik Dona, 3, (2013)

2. A.V. Gridnevskiy, R.B. Matveiko, Scientific review, 11-3, 678-681 (2014)

3. A.V. Gridnevskiy, AA. Hamavova, Scientific review, 11, 83-386 (2014)

4. S.G. Sheina, L.V. Girya, Inzhenernyy Vestnik Dona, 3, (2012)

5. L.V Girya, V.V Belash., S. V. Horenkov, K. S. Petrov, Inzhenernyy Vestnik Dona, 4, (2013)

6. Russian Standard VSN 53-86

7. Software by EXELIS VIS:ENVI and SARscape Interferometric Stacking.

8. P.O. Skobelev, E.V. Simonova, A.A. Zhilyaev, V.S. Travin. Procedia Computer Science, 103, 396-402 (2017)

9. S.M. Gandhi, B.C. Sarkar. Chapter 4, Remote Sensing Techniques, Essentials of Mineral Exploration and Evaluation, 81-95 (2016) 